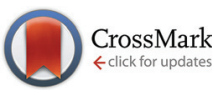

Cite this: Org. Biomol. Chem., 2016, 14,3744

Received 28th January 2016,

Accepted 10th March 2016

DOI: 10.1039/c6ob00241b

www.rsc.org/obc

\title{
Evaluation of the transfection efficacies of quaternary ammonium salts prepared from sophorolipids $\uparrow$
}

\author{
E. I. P. Delbeke, ${ }^{a}$ O. Lozach, ${ }^{b}$ T. Le Gall, ${ }^{c, d}$ M. Berchel, ${ }^{b, c}$ T. Montier, ${ }^{c, d, e, f}$ \\ P.-A. Jaffrès, ${ }^{b, c}$ K. M. Van Geem ${ }^{g}$ and C. V. Stevens ${ }^{* a}$
}

\begin{abstract}
Five quaternary ammonium amphiphilic compounds were synthesized from sophorolipid 1 . These compounds were formulated in aqueous media and some of them (5 and 6) produced well-defined supramolecular aggregates which were characterized by DLS and zeta measurements. Their capacity to transfect four different eukaryotic cell lines in vitro was assessed. To evaluate the influence of the carbohydrate head group from the sophorolipids on the transfection efficacies, their deglycosylated analogues were also synthesized and tested for gene delivery. For all the compounds, the use of DOPE as a helper lipid in a 1:1 molar ratio with the ammonium-based lipids was required to obtain homogeneous formulations. The transfection results indicate that quaternary ammonium-based sophorolipids proved to be more efficient pDNA carriers than their deglycosylated counterparts. Moreover, the presence of the carbohydrate head group clearly contributed to the good biocompatibility of these cationic lipids. These cationic sophorolipid derivatives thus offer good potential for the development of new vectors for gene delivery based on renewable resources.
\end{abstract}

\section{Introduction}

Cationic lipids constitute a class of amphiphilic compounds which can be used to compact, protect and carry pDNA or other nucleic acids such as mRNA, ${ }^{1}$ shRNA or siRNA ${ }^{2}$ for in vitro or in vivo applications. ${ }^{3}$ This class of vectors was initially used by Felgner et al. ${ }^{4}$ Since then, many types of cationic lipids have been designed, leading to a better under-

\footnotetext{
${ }^{a}$ SynBioC, Department of Sustainable Organic Chemistry and Technology, Ghent University, Coupure Linkes 653, 9000 Ghent, Belgium.

E-mail: Chris.Stevens@UGent.be

${ }^{b}$ Université de Brest, CEMCA, CNRS UMR 6521, IBSAM, 6 avenue Le Gorgeu, 29238 Brest, France

'IBiSA SynNanoVect platform, IBSAM, Université de Brest, Faculté de médecine Morvan, avenue Camille Desmoulins, 46 rue Félix Le Dantec, CS 51819, 29218 Brest Cedex 2, France

${ }^{d}$ Université de Brest, INSERM UMR 1078, IBSAM, Faculté de médecine Morvan, avenue Camille Desmoulins, 46 rue Félix Le Dantec, CS 51819, 29218 Brest Cedex 2, France

${ }^{e}$ CHRU de Brest, Service de Génétique Moléculaire et d'Histocompatibilité, 5 avenue de Maréchal Foch, 29609 Brest cedex, France

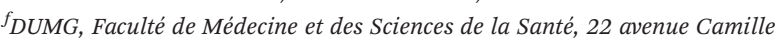
Desmoulins, 29328 Brest, France

${ }^{g}$ LCT, Department of Chemical Engineering and Technical Chemistry,

Ghent University, Technologiepark 914, 9052 Ghentn, Belgium

$\dagger$ Electronic supplementary information (ESI) available. See DOI: 10.1039/ c6ob00241b
}

standing of the mode of action and the identification of efficient vectors. ${ }^{5}$ For example, recent clinical trials demonstrated some benefits of the administration of CFTR genes to cystic fibrosis patients using a cationic lipid as a carrier. ${ }^{6}$ Moreover, synthetic vectors such as cationic lipids can be administered multiple times without any side reaction, in contrast to viral vectors which are efficient carriers for transfection but can induce an immune response from the first administration. ${ }^{7}$ Many cationic lipids possess a structure inspired by natural amphiphilic compounds such as phospholipids with the aim to produce non-toxic or low-toxic vectors. ${ }^{8}$ Recently, research has been focused on the development of renewable based gene delivery vectors, since natural derived products are expected to have an enhanced biocompatibility. ${ }^{9}$ Glycerolbased cationic lipids were widely studied and cationic lipids with natural lipid chains such as oleyl, linoleyl or phytanyl chains were used to produce efficient vectors. ${ }^{9 a-d}$ MacDonald and co-workers alkylated natural diacylglycerophosphocholine to produce cationic lipids. ${ }^{9 e-g}$ Aminoglycosides, sperminebased vectors and trimethylarsonium-based compounds (these latter being widely present in sea food) were also incorporated as cationic polar heads to produce efficient vectors for gene delivery. ${ }^{3 b, 9 h-n, 10}$ Therefore, the assessment of new natural resources which can be chemically modified to design new cationic amphiphilic compounds for nucleic acid delivery is of great interest. 
Sophorolipids are a class of biosurfactants which are produced by the yeast Starmerella bombicola through fermentation using glucose as the hydrophilic carbon source and a fatty acid, mostly oleic acid, as the hydrophobic carbon source. ${ }^{11}$ Natural sophorolipids feature multiple beneficial biological activities such as anti-cancer, antimicrobial, dermatological, immunoregulatory, spermicidal and antiviral activities. ${ }^{12}$ They also possess self-assembly properties, which resulted in the synthesis of supramolecular nanostructures and the use of sophorolipids as capping agents for nanoparticle formation. ${ }^{12 e, 13}$ Some authors even suggested the possibility that sophorolipid-capped nanoparticles could be able to cross the blood-brain barrier for targeted drug delivery. ${ }^{14}$ All the previous examples suggest that cationic sophorolipid derivatives can be considered as suitable vectors for gene delivery. Recently in our research group, a library of eighteen quaternary ammonium sophorolipids was successfully synthesized and promising antimicrobial activities were obtained for these new derivatives. ${ }^{15}$

In this work, the evaluation of the transfection efficiency for the previously synthesized quaternary ammonium sophorolipids is described. To evaluate the influence of the carbohydrate head group, its deglycosylated derivatives were also prepared and compared with the quaternary ammonium sophorolipids for in vitro experiments. A commercial lipofection reagent was used as a reference compound in the transfection experiments.

\section{Results and discussion}

The synthesis of a quaternary ammonium sophorolipid library was previously described in six steps starting from the major microbial product, i.e. the diacetylated sophorolipid lactone $1{ }^{15}$ Among a set of 18 quaternary ammonium sophorolipids, 5 compounds (2-6) were evaluated for their ability to form supramolecular aggregates in aqueous solution by using the method of hydration of a lipid film. These formulations were characterized by measuring the size of the nanoparticles (DLS measurements) and their surface charge (zeta measurements) (Scheme 1 and Table 1). The formation of a homogeneous formulation is a necessary prerequisite for the evaluation of the suitability of quaternary ammonium sophorolipids as vectors for gene delivery. In this series of compounds, only com-
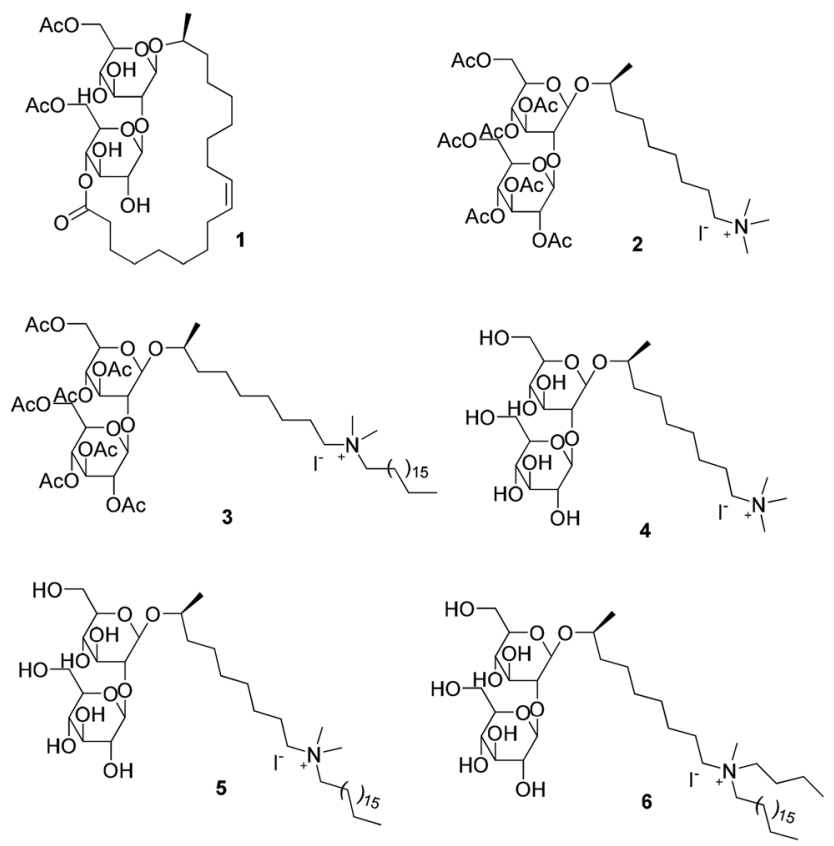

Scheme 1 Chemical structure of diacetylated sophorolipid lactone 1, acetylated quaternary ammonium sophorolipids 2 and 3 and deprotected quaternary ammonium sophorolipids 4-6.

pounds 5 and $\mathbf{6}$ produced homogeneous formulations. For the other compounds their weak amphiphilic character (limited hydrophobic domain) likely explained the absence of well characterized nanoparticles in water. Quaternary ammonium sophorolipids 5 and 6 were subsequently evaluated with respect to their transfection efficiency. In order to elucidate the importance of the disaccharide unit specifically present in compounds 5 and $\mathbf{6 ,} 4$ analogues $(\mathbf{9 a} / \mathbf{b}$ and $\mathbf{1 1 a} / \mathbf{b})$ devoid of this motif were synthesized for this study (Scheme 2).

In a first step, the synthesis of hydroxylated quaternary ammonium salts 9 was attempted starting from $N$-methyl, $N$ octadecyl sophorolipid amine 7 (Scheme 2A). The sophorolipid amine was subjected to acid hydrolysis, followed by automated flash purification of (S)-9-(methyl(octadecyl)amino)nonan-2-ol 8, and subsequent quaternization with methyl and butyl iodide towards hydroxylated quarternary ammonium salts $\mathbf{9}$. These compounds possess a sub-terminal hydroxyl function, resulting from the stereoselective hydroxylation of the fatty acid in the fermentation process. Since this hydroxyl function

Table 1 Size and zeta potential measurements of liposomal solutions prepared at $1.5 \mathrm{mM}$ without (left) or with (right) DOPE

\begin{tabular}{|c|c|c|c|c|c|c|}
\hline & \multirow[b]{2}{*}{ Size $(\mathrm{nm})$} & \multirow[b]{2}{*}{ Polydisp. Index } & \multirow[b]{2}{*}{ Zeta $(\mathrm{mV})$} & Size $(n m)$ & Polydisp. Index & Zeta $(\mathrm{mV})$ \\
\hline & & & & \multicolumn{3}{|l|}{$+\mathrm{DOPE}$} \\
\hline 5 & $186 \pm 110$ & 0.94 & 29.9 & $54 \pm 0.5$ & 0.22 & 49.2 \\
\hline 6 & $275 \pm 49$ & 0.56 & 27.9 & $94 \pm 0.1$ & 0.20 & 40.8 \\
\hline 9a & $288 \pm 23$ & 0.53 & 35.9 & $35 \pm 0.7$ & 0.36 & 49.1 \\
\hline $9 b$ & $289 \pm 9$ & 0.30 & 27.6 & $43 \pm 0.8$ & 0.28 & 49.4 \\
\hline $11 a$ & $169 \pm 2$ & 0.34 & 42.4 & $47 \pm 0.9$ & 0.40 & 51.0 \\
\hline $11 b$ & $212 \pm 5$ & 0.37 & 24.7 & $78 \pm 1.2$ & 0.27 & 52.9 \\
\hline
\end{tabular}


A:

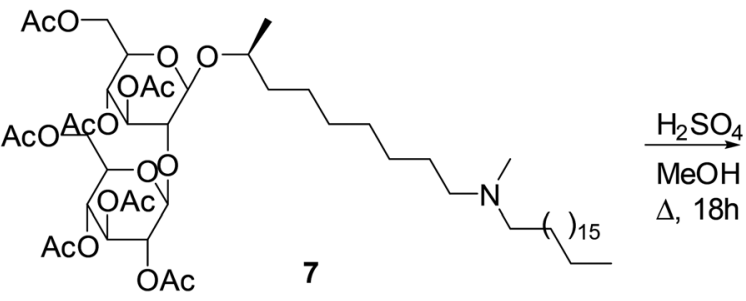

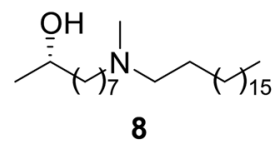

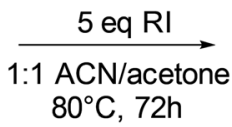

$80^{\circ} \mathrm{C}, 72 \mathrm{~h}$

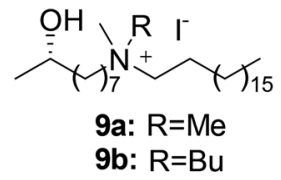<smiles>CCCCCCCCC=O</smiles>

B:<smiles>CNCCC(C)C</smiles>

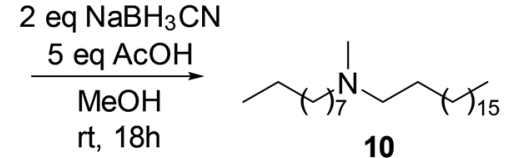

10

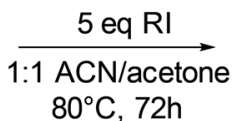

$80^{\circ} \mathrm{C}, 72 \mathrm{~h}$

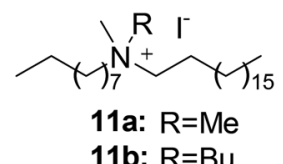

Scheme 2 Synthesis of hydroxylated and non-hydroxylated quaternary ammonium salts 9 and 11.

could also influence the amphiphilic properties of the quaternary ammonium salts, synthesis of the non-hydroxylated quaternary ammonium salts $\mathbf{1 1}$ was attempted as well (Scheme 2B). $N$-Methyl, $N$-nonyloctadecan-1-amine 10 was synthesized via reductive amination of nonanal and $N$-methyl, $N$ octadecylamine, followed by quaternization with methyl and butyl iodide towards non-hydroxylated quaternary ammonium salts 11 (see the ESI $\dagger$ for ${ }^{1} \mathrm{H}$ and ${ }^{13} \mathrm{C} N M R$ ).

Quaternary ammonium sophorolipids 5 and 6, the hydroxylated quaternary ammonium salts $\mathbf{9 a} / \mathbf{b}$ and the non-hydroxylated quaternary ammonium salts $\mathbf{1 1 a} / \mathbf{b}$ were formulated as a liposomal solution. All the compounds were formulated with or without 1,2-dioleoyl-sn-glycero-3-phosphoethanolamine (DOPE). For all liposomal solutions, the size and zeta potential were determined (Table 1). Particularly, for the quaternary ammonium sophorolipids $\mathbf{5}$ and $\mathbf{6}$, and to a lesser extent for hydroxylated quaternary ammonium salts $\mathbf{9 a} / \mathbf{b}$, formulation with DOPE proved to be necessary to obtain homogeneous formulations. Formulations with DOPE also resulted in the formation of much smaller particles in comparison with formulations without DOPE. All zeta potentials were clearly positive as expected for liposomes generated from cationic lipid derivatives.

The capacity to compact plasmid DNA (pDNA) was evaluated for all liposomal formulations by pDNA retardation assays on agarose gel electrophoresis (Fig. 1). This was performed at different charge ratios (CR) which is defined as the number of positive charges provided by the cationic lipid derivative divided by the number of negative charges carried by the pDNA. In the absence of any co-lipid, no pDNA compaction was observed for any of the six compounds (see ESI $1 \dagger$ ). When formulated with DOPE, quaternary ammonium sophorolipids 5 and $\mathbf{6}$ still remained almost inefficient to compact pDNA. For hydroxylated quaternary ammonium salts $\mathbf{9 a} / \mathbf{b}$, very weak compaction was observed. Only both non-hydroxylated quaternary ammonium salts $\mathbf{1 1 a} / \mathbf{b}$ demonstrated some ability to compact pDNA, on a similar level as LFM. Altogether, these results suggest that a better compaction of pDNA is obtained for less hydrophilic compounds.
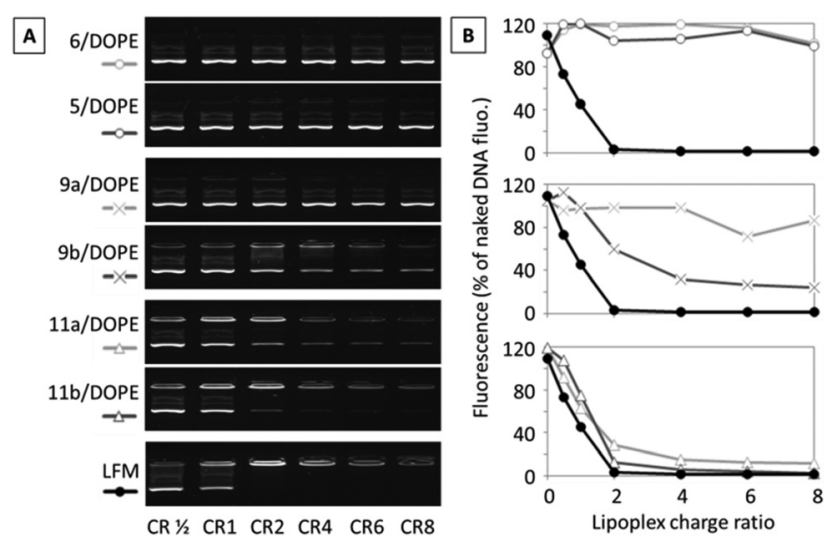

Fig. 1 Ability for pDNA complexation of quaternary ammonium sophorolipids 5 and 6 , hydroxylated quaternary ammonium salts $9 \mathrm{a} / \mathrm{b}$ and non-hydroxylated quaternary ammonium salts $11 \mathrm{a} / \mathrm{b}$ at various $\mathrm{CR}$. For each compound, the profile of retardation assay (panel A) and the corresponding relative fluorescence intensity (panel B) of the lower DNA band (i.e. the supercoiled pDNA form) are shown. The results obtained with the reference lipofection agent LFM are provided in panel $A$ and in each graph of panel $B$.

The cationic lipids were then evaluated with respect to their ability to deliver DNA to various cell lines. Three humanderived cell lines were included, namely melanoma cells (SKMEL28) and two airway epithelial cells i.e. (i) lung carcinoma (A549) and (ii) normal bronchial (16HBE) cells. A fourth cell line was a mouse myoblast cell line (C2C12) which was only used for the evaluation of the formulations incorporating DOPE. A reporter (luciferase-encoding) pDNA was used that allowed the determination of the transfection efficiency via highly sensitive luminescence measurements. Each formulation was evaluated at different CRs, similar to those previously considered for the DNA complexation assay.

Concerning the efficiency of liposomes prepared without DOPE, only the ones derived from non-hydroxylated quaternary ammonium salts $\mathbf{1 1 a} / \mathbf{b}$ were able to transfect one of the cell lines studied (16HBE). All the other liposomes devoid of DOPE were completely inefficient to transfect any of the 


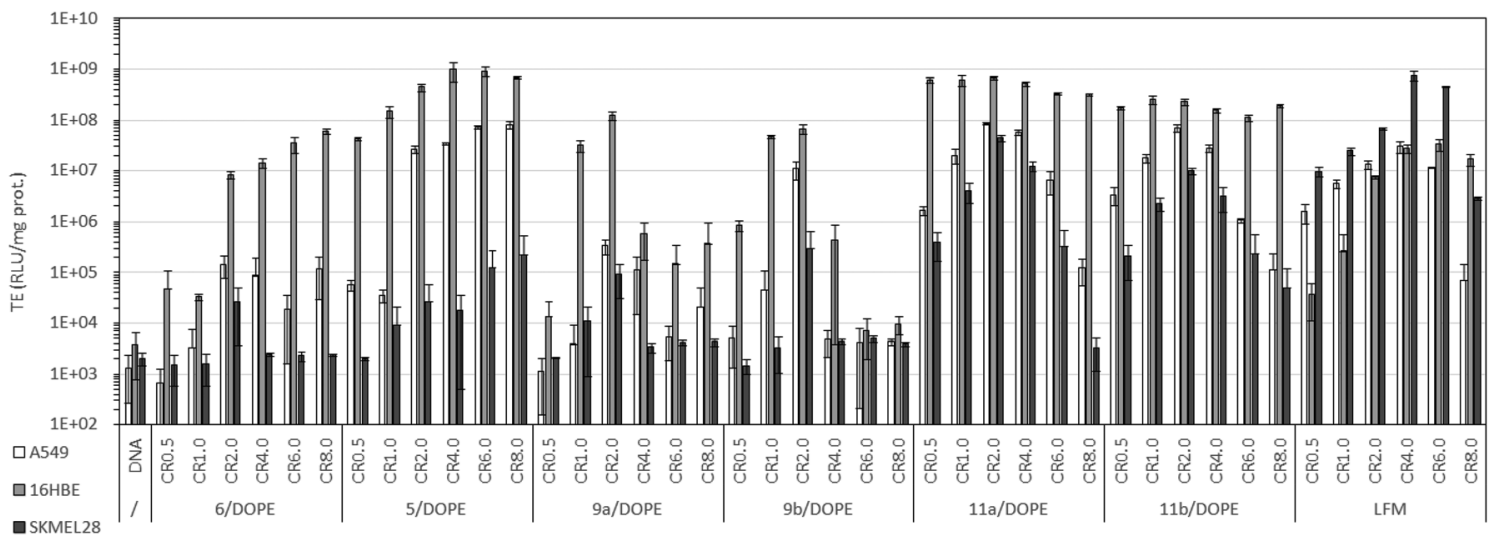

Fig. 2 Transfection efficacies (TE) of quaternary ammonium sophorolipids 5 and 6 , hydroxylated quaternary ammonium salts $9 a / b$ and nonhydroxylated quaternary ammonium salts $11 \mathrm{a} / \mathrm{b}$, all formulated with DOPE, on three cell lines (A549, 16HBE, and SKMEL28) using luciferase-encoding pDNA. TE are expressed in RLU per mg of proteins $(n=3)$. Lipofectamine (LFM) and naked (uncomplexed) pDNA were used as positive and negative controls, respectively.

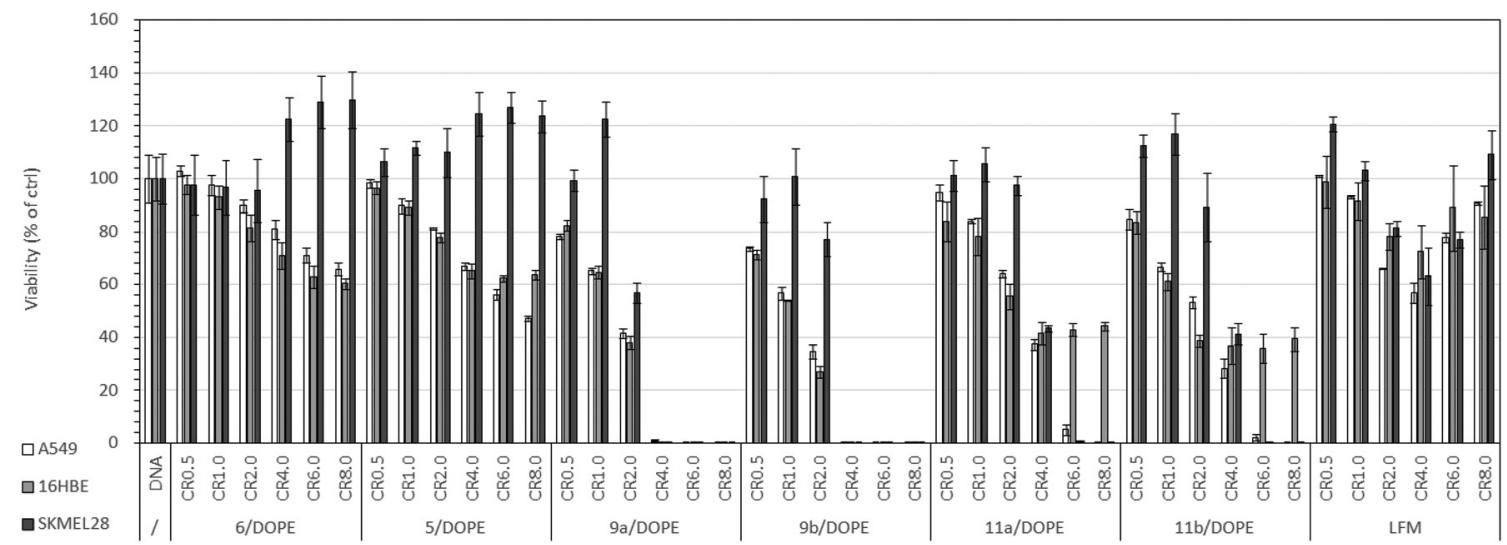

Fig. 3 Cell viability determined $48 \mathrm{~h}$ after incubation of the cells with lipoplexes prepared with quaternary ammonium sophorolipids 5 and 6 , hydroxylated quaternary ammonium salts $9 \mathrm{a} / \mathrm{b}$ and non-hydroxylated quaternary ammonium salts $11 \mathrm{a} / \mathrm{b}$, all formulated with DOPE. Naked pDNA was used as the negative control. Values are expressed as a percentage of the viability determined with untransfected cells.

considered cell lines (see ESI 2 and $3 \dagger$ ). On the contrary, when formulated with DOPE, all derivatives demonstrated some ability to transfect one or more cell lines (Fig. 2 and ESI $4 \dagger$ that also include some results with the $\mathrm{C} 2 \mathrm{C} 12$ cell line). The quaternary ammonium sophorolipids $\mathbf{5}$ and $\mathbf{6}$ efficiently transfected 16HBE and A549 cell lines, whereas lower efficiencies were obtained for the transfection of the SKMEL28 cell line. This observation could be related to the low compaction properties of the formulations of compounds 5 and $\mathbf{6}$ with DOPE as shown in Fig. 1. Two hypotheses can be formulated: (1) compared to cell lines A549 and 16HBE, the cell line SKMEL28 requires efficient pDNA compacting agents to observe transfection that likely occurs via an endocytosis pathway. This hypothesis is consistent with the compaction properties of compounds $\mathbf{1 1 a} / \mathbf{b}$ or LFM and their respective transfection efficacies. (2) The second hypothesis would implicate a different mechanism that could involve the temporary poration of the membrane which was recently observed by Ilies and coworkers for another kind of cationic lipid. ${ }^{16}$ The quaternary ammonium salts $\mathbf{9 a / b}$ and $\mathbf{1 1 a} / \mathbf{b}$ were also efficient to deliver the pDNA to all four cell lines with the best results obtained at CR2 or CR4. It can be noticed that the chemical structure of $\mathbf{1 1 a} / \mathbf{b}$ is close to that of didodecyldimethylammonium bromide (DDAB) ${ }^{17}$ or dodecyltrimethylammonium ${ }^{18}$ which were reported previously as vectors for gene delivery.

Regarding the toxicity of the different compounds, it is noteworthy that they exhibited quite different effects towards the viability of the cells (Fig. 3 and ESI $5 \dagger$ for the C2C12 cell line). However, these effects were similar whether or not DOPE was incorporated into the formulation (see ESI 6 and $7 \dagger$ ). Quaternary ammonium salts $\mathbf{9 a} / \mathbf{b}$ and $\mathbf{1 1 a} / \mathbf{b}$ were highly detrimental for the cells from a CR as low as 2 . This high toxicity was clearly associated with a decrease of the transfection efficacy at CR higher than 2 (Fig. 2). This may be explained by a detergent effect exerted by these cationic amphiphilic compounds. On the contrary, quaternary ammonium sophorolipids 5 and $\mathbf{6}$ 
were much better tolerated by the cells. Indeed, no real toxicity against SKMEL28 and only a moderate CR-dependent toxicity towards the three other cell lines were noticed. These results strongly suggest that the biocompatibility of sophorolipids is at least in part - due to the sugar group they specifically incorporate. Hence, despite that quaternary ammonium sophorolipids 5 and 6 poorly interacted with pDNA, they were clearly more efficient transfection vectors than their deglycosylated analogues $\mathbf{9 a} / \mathbf{b}$ and $\mathbf{1 1 a} / \mathbf{b}$. Many recent reports highlight that there is no strict relationship between the ability of a given vector to retard DNA on agarose gel and its ability to transfect cells in vitro. Actually, a balance should be found between stability of complexes (in order to form aggregates dense enough to contact and enter cells) and lability (to release DNA once inside the cells). ${ }^{9 c, 19}$ However, no general conclusion can be drawn since such an equilibrium might depend on many parameters including the cationic lipid considered, the experimental conditions employed (e.g. the medium used to prepare the lipoplexes), the cells to be treated, etc. Such a balance may also determine the toxicity experienced by the cells.

\section{Conclusions}

From a starting set of 18 chemically synthesized quaternary ammonium sophorolipids, two (5 and 6) were retained and evaluated as possible vectors for gene delivery. To evaluate the influence of the carbohydrate head group, their deglycosylated derivatives $\mathbf{9 a} / \mathbf{b}$ and $\mathbf{1 1 a} / \mathbf{b}$ were synthesized. In particular, hydroxylated quaternary ammonium salts $\mathbf{9}$ and non-hydroxylated quaternary ammonium salts $\mathbf{1 1}$ were synthesized. All six cationic lipid derivatives were formulated as a liposomal solution and characterized (size, zeta potential). For these formulations, the use of DOPE as a helper lipid was included. Its presence was required to obtain homogeneous liposomal solutions with the quaternary ammonium sophorolipids 5 and $\mathbf{6}$. Then, the ability of the liposomal formulations to compact pDNA was assessed. An increasing compaction was observed for a decreasing hydrophilicity of the compounds and formulation with DOPE proved to be necessary.

Finally, the capacity of the cationic lipids 5, 6, 9a/b and $\mathbf{1 1 a} / \mathbf{b}$ to achieve transfection of eukaryotic cells was assessed on three cell lines (A549, 16HBE, and SKMEL28). The transfection efficacies depended on the $\mathrm{CR}$ and the quaternary ammonium sophorolipids 5 and $\mathbf{6}$ exhibited high transfection results concomitantly with a low cell toxicity. We provide evidence that the disaccharide moiety present in compounds 5 and 6 contributed to their low toxicity. This work illustrates the valorization of natural resources for the development of highly biocompatible transfection agents.

\section{Experimental}

\section{Synthetic procedures}

General procedure for synthesis of $(S)$-9-(methyl(octadecyl) amino)nonan-2-ol (8). $N$-Methyl, $N$-octadecyl sophorolipid amine 7 ( $0.76 \mathrm{~g}, 0.73 \mathrm{mmol})$ was dissolved in $20 \mathrm{~mL}$ methanol, a few drops of concentrated sulfuric acid were added, and the mixture was refluxed overnight. Subsequently, an aqueous $2 \mathrm{~N}$ sodium hydroxide solution was added until an alkaline $\mathrm{pH}$ was obtained. The organic solvent was evaporated under reduced pressure and the resulting water layer was extracted with diethyl ether. The organic phase was dried over magnesium sulfate, filtered and concentrated under reduced pressure. Compound $\mathbf{8}$ was purified via automated flash chromatography with a hexane/ethyl acetate/triethylamine mixture as the eluent. Purification gradient: $2 \mathrm{CV} 5 \%$ mixture A, 30 CV 5-60\% mixture A, and 2 CV 60\% mixture A (mixture $\mathrm{A}=16 \%$ triethylamine in ethyl acetate). Compound 8 was isolated as a viscous colorless oil (0.13 g, 43\%). ${ }^{1} \mathbf{H}-\mathbf{N M R}$ $\left(400 \mathrm{MHz}, \mathrm{CDCl}_{3}\right): \delta_{\mathbf{H}} 0.88\left(3 \mathrm{H}, \mathrm{t}, J=6.9 \mathrm{~Hz}, \mathrm{CH}_{3} \mathrm{CH}_{2}\right), 1.18$ $\left(3 \mathrm{H}, \mathrm{d}, J=6.2 \mathrm{~Hz}, \mathrm{CH}_{3} \mathrm{CH}\right), 1.25-1.35\left(38 \mathrm{H}, \mathrm{m}, \mathrm{CH}_{3} \mathrm{CH}_{2}, 18 \times\right.$ $\left.\mathrm{C}_{2}\left(\mathrm{CH}_{2}\right)_{2}\right), 1.38-1.49\left(6 \mathrm{H}, \mathrm{m}, 2 \times \mathrm{CH}_{2} \mathrm{CH}_{2} \mathrm{~N}, \mathrm{CH}_{2} \overline{C H C H}_{3}\right)$, $1.94(1 \mathrm{H}$, br s, OH$), 2.20\left(3 \mathrm{H}, \mathrm{s}, \mathrm{CH}_{3} \mathrm{~N}\right), 2.28-2.32(4 \mathrm{H}, \mathrm{m}, 2 \times$ $\mathrm{CH}_{2} \mathrm{CH}_{2} \mathrm{~N}$ ), 3.74-3.82 (1H, m, CHOH). ${ }^{13} \mathrm{C}-\mathrm{NMR}(100 \mathrm{MHz}$, $\left.\mathbf{C D C l}_{3}\right): \delta_{\mathbf{C}} 14.1\left(\underline{\mathrm{CH}}_{3} \mathrm{CH}_{2}\right), 22.7\left(\mathrm{CH}_{3} \underline{C H}_{2}\right), 23.5\left(\underline{\mathrm{CH}}_{3} \mathrm{CH}\right), 25.7$ $\left(\mathrm{CH}_{2}\left(\mathrm{CH}_{2}\right)_{2}\right), 27.2\left(2 \times \underline{\mathrm{CH}}_{2} \mathrm{CH}_{2} \mathrm{~N}\right), 27.6\left(\mathrm{CH}_{2}\left(\mathrm{CH}_{2}\right)_{2}\right), 27.7$ $\left(\underline{\mathrm{CH}_{2}}\left(\mathrm{CH}_{2}\right)_{2}\right), 29.4\left(\mathrm{CH}_{2}\left(\mathrm{CH}_{2}\right)_{2}\right), 29.6-29.7\left(13 \times \underline{\mathrm{CH}}_{2}\left(\mathrm{CH}_{2}\right)_{2}\right)$, $31.9\left(\mathrm{CH}_{2}\left(\mathrm{CH}_{2}\right)_{2}\right), 39.4\left(\underline{\mathrm{CH}}_{2} \mathrm{CHCH}_{3}\right), 41.3\left(\underline{\mathrm{CH}}_{3} \mathrm{~N}\right), \overline{7} .9\left(\underline{\mathrm{CH}}_{2} \mathrm{~N}\right)$, $57.9\left(\underline{\mathrm{C}}_{2} \mathrm{~N}\right), 68.1(\underline{\mathrm{CHOH}})$. MS (ESI): $\boldsymbol{m} / z$ exact mass calculated for $\mathrm{C}_{28} \mathrm{H}_{60} \mathrm{NO}\left[\mathrm{M}+\mathrm{H}^{+}\right]$: 426.4669 . Found: 426.4655 .

General procedure for synthesis of $N$-((S)-8-hydroxynonyl)$\boldsymbol{N}, \boldsymbol{N}$-dimethyloctadecan-1-ammonium iodide (9a). In a $10 \mathrm{~mL}$ pressure resistant vial, $0.071 \mathrm{~g}$ of compound $8(0.17 \mathrm{mmol})$ was dissolved in a 1:1 mixture of acetone and acetonitrile. The solution was cooled down to $0{ }^{\circ} \mathrm{C}$ and $0.05 \mathrm{~mL}$ of methyl iodide ( $0.83 \mathrm{mmol}, 5$ eq.) was added. The vial was closed and heated to $80^{\circ} \mathrm{C}$ for 72 hours. The reaction mixture was concentrated under reduced pressure to yield compound 9a as a yellow waxy solid (0.097 g, 98\%). ${ }^{\mathbf{1}} \mathbf{H}-\mathbf{N M R}$ (400 $\mathbf{M H z}, \mathbf{C D C l}_{3}$ ): $\delta_{\mathbf{H}} 0.88\left(3 \mathrm{H}, \mathrm{t}, J=6.8 \mathrm{~Hz}, \mathrm{CH}_{3} \mathrm{CH}_{2}\right), 1.19(3 \mathrm{H}, \mathrm{d}, J=6.2 \mathrm{~Hz}$, $\left.\mathrm{CH}_{3} \mathrm{CH}\right), \quad 1.26-1.46\left(40 \mathrm{H}, \mathrm{m}, \mathrm{CH}_{2} \mathrm{CHCH}_{3}, \mathrm{CH}_{3} \mathrm{CH}_{2}, 18 \times\right.$ $\left.\mathrm{CH}_{2}\left(\mathrm{CH}_{2}\right)_{2}\right), 1.68-1.77\left(4 \mathrm{H}, \mathrm{m}, 2 \times \mathrm{CH}_{2} \mathrm{CH}_{2} \mathrm{~N}\right), 3.38(6 \mathrm{H}, \mathrm{s}, 2 \times$ $\left.\mathrm{C}_{3} \mathrm{~N}\right), 3.46-3.52\left(2 \mathrm{H}, \mathrm{m}, \mathrm{CH}_{2} \mathrm{~N}\right), 3.53-3.58\left(2 \mathrm{H}, \mathrm{m}, \mathrm{CH}_{2} \mathrm{~N}\right)$, $3.67(1 \mathrm{H}, \mathrm{s}, \mathrm{CHOH}), 3.77-3.84(1 \mathrm{H}, \mathrm{m}, \mathrm{CHOH}) .{ }^{13} \mathrm{C}-\mathbf{N M R}$ $\left(100 \mathrm{MHz}, \mathbf{C D C l}_{3}\right): \delta_{\mathrm{C}} 14.1\left(\underline{\mathrm{CH}}_{3} \mathrm{CH}_{2}\right), 22.7\left(2 \times \underline{\mathrm{CH}}_{2} \mathrm{CH}_{2} \mathrm{~N}\right), 22.8$ $\left(\mathrm{CH}_{3} \underline{\mathrm{CH}}_{2}\right), 23.6\left(\underline{\mathrm{CH}}_{3} \mathrm{CH}\right), 25.4\left(\underline{\mathrm{CH}}_{2}\left(\mathrm{CH}_{2}\right)_{2}\right), 25.9\left(\underline{\mathrm{CH}}_{2}\left(\mathrm{CH}_{2}\right)_{2}\right)$, $26.2\left(\underline{\mathrm{CH}}_{2}\left(\mathrm{CH}_{2}\right)_{2}\right), 28.9\left(\mathrm{CH}_{2}\left(\mathrm{CH}_{2}\right)_{2}\right), 29.1\left(\underline{\mathrm{CH}}_{2}\left(\mathrm{CH}_{2}\right)_{2}\right), 29.2$

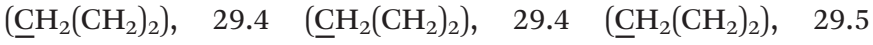
$\left(\underline{\mathrm{CH}}_{2}\left(\mathrm{CH}_{2}\right)_{2}\right), 29.6\left(\underline{\mathrm{CH}}_{2}\left(\mathrm{CH}_{2}\right)_{2}\right), 29.7\left(7 \times \underline{\mathrm{CH}}_{2}\left(\mathrm{CH}_{2}\right)_{2}\right), 31.9$ $\left(\underline{\mathrm{C}}_{2}\left(\mathrm{CH}_{2}\right)_{2}\right), 39.0\left(\underline{\mathrm{CH}}_{2} \mathrm{CHCH}_{3}\right), 51.5\left(2 \times \underline{\mathrm{C}}_{3} \mathrm{~N}\right), 64.4(2 \times$ $\left.\mathrm{CH}_{2} \mathrm{~N}\right), 67.9(\underline{\mathrm{CHOH}}) . \mathbf{M S}(\mathrm{ESI}): \boldsymbol{m} / z$ exact mass calculated for $\mathrm{C}_{29} \mathrm{H}_{62} \mathrm{NO}\left[\mathrm{M}-\mathrm{I}^{-}\right]:$440.4826. Found: 440.4843.

General procedure for synthesis of $N$-butyl, $N-((S)$-8-hydroxynonyl)- $N$-methyloctadecan-1-ammonium iodide (9b). In a $10 \mathrm{~mL}$ pressure resistant vial, $0.063 \mathrm{~g}$ of compound 8 (0.15 mmol) was dissolved in a 1:1 mixture of acetone and acetonitrile. The solution was cooled down to $0{ }^{\circ} \mathrm{C}$ and $0.08 \mathrm{~mL}$ of butyl iodide ( $0.74 \mathrm{mmol}, 5 \mathrm{eq}$.) was added. The vial was closed and heated to $80{ }^{\circ} \mathrm{C}$ for 72 hours. The reaction mixture was concentrated under reduced pressure to yield compound 9b as a yellow waxy solid (0.099 g, 87\%). ${ }^{\mathbf{1}} \mathbf{H}-\mathbf{N M R}$ 
(400 $\left.\mathrm{MHz}, \mathrm{CDCl}_{3}\right): \delta_{\mathbf{H}} 0.88\left(3 \mathrm{H}, \mathrm{t}, J=6.8 \mathrm{~Hz}, \mathrm{CH}_{3} \mathrm{CH}_{2}\right), 1.02$ $\left(3 \mathrm{H}, \mathrm{t}, J=7.3 \mathrm{~Hz}, \mathrm{CH}_{3} \mathrm{CH}_{2}\right), 1.19\left(3 \mathrm{H}, \mathrm{d}, J=6.2 \mathrm{~Hz}, \mathrm{CH}_{3} \mathrm{CH}\right)$, 1.26-1.50 (42H, m, $\left.\underline{\mathrm{CH}}_{2} \mathrm{CHCH}_{3}, 2 \times \mathrm{CH}_{3} \underline{\mathrm{CH}}_{2}, 18 \times \mathrm{CH}_{2}\left(\overline{\mathrm{CH}}_{2}\right)_{2}\right)$, 1.65-1.74 (6H, m, $\left.3 \times \mathrm{CH}_{2} \mathrm{CH}_{2} \mathrm{~N}\right), 3.31\left(3 \mathrm{H}, \mathrm{s}, \mathrm{C}_{3} \mathrm{~N}\right), 3.40-3.49$ $\left(6 \mathrm{H}, \mathrm{m}, 3 \times \mathrm{CH}_{2} \mathrm{~N}\right), 3.67(1 \mathrm{H}, \mathrm{s}, \mathrm{CHOH}), 3.77-3.84(1 \mathrm{H}, \mathrm{m}$, CㅂH). ${ }^{13} \mathrm{C}-\mathrm{NMR}\left(100 \mathrm{MHz}, \mathrm{CDCl}_{3}\right): \delta_{\mathrm{C}} 13.8\left(\mathrm{CH}_{3} \mathrm{CH}_{2}\right), 14.1$ $\left(\underline{\mathrm{CH}}_{3} \mathrm{CH}_{2}\right), 19.7\left(\mathrm{CH}_{3} \underline{\mathrm{CH}}_{2}\right), 22.5\left(\underline{\mathrm{CH}}_{2} \mathrm{CH}_{2} \mathrm{~N}\right), 22.5\left(\underline{\mathrm{CH}}_{2} \mathrm{CH}_{2} \mathrm{~N}\right)$, $22.7 \quad\left(\mathrm{CH}_{3} \underline{\mathrm{CH}}_{2}\right), \quad 23.6 \quad\left(\underline{\mathrm{CH}}_{3} \mathrm{CH}\right), \quad 24.4 \quad\left(\underline{\mathrm{CH}}_{2} \mathrm{CH}_{2} \mathrm{~N}\right), \quad 25.4$

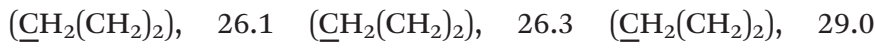
$\begin{array}{llllll}\left(\underline{\mathrm{CH}}_{2}\left(\mathrm{CH}_{2}\right)_{2}\right), & 29.1 & \left(\underline{\mathrm{CH}}_{2}\left(\mathrm{CH}_{2}\right)_{2}\right), & 29.2 & \left(\underline{\mathrm{CH}}_{2}\left(\mathrm{CH}_{2}\right)_{2}\right), & 29.4\end{array}$ $\begin{array}{lllll}\left(\underline{\mathrm{CH}}_{2}\left(\mathrm{CH}_{2}\right)_{2}\right), & 29.4 & \left(\underline{\mathrm{C}}_{2}\left(\mathrm{CH}_{2}\right)_{2}\right), \quad 29.5 & \left(\underline{\mathrm{CH}}_{2}\left(\mathrm{CH}_{2}\right)_{2}\right), & 29.6\end{array}$ $\left(\underline{\mathrm{C}} \mathrm{H}_{2}\left(\mathrm{CH}_{2}\right)_{2}\right), 29.7\left(7 \times \underline{\mathrm{CH}_{2}}\left(\mathrm{CH}_{2}\right)_{2}\right), 31.9\left(\underline{\mathrm{CH}}_{2}\left(\mathrm{CH}_{2}\right)_{2}\right), 39.0$ $\left(\underline{\mathrm{CH}}_{2} \mathrm{CHCH}_{3}\right), 49.2\left(\underline{\mathrm{CH}}_{3} \mathrm{~N}\right), 61.6\left(\underline{\mathrm{CH}}_{2} \mathrm{~N}\right), 61.7\left(\underline{\mathrm{CH}}_{2} \mathrm{~N}\right), 61.9$ $\left(\underline{\mathrm{CH}}_{2} \mathrm{~N}\right), 67.9(\underline{\mathrm{CHOH}})$. MS (ESI): $\boldsymbol{m} / z$ exact mass calculated for $\mathrm{C}_{32} \mathrm{H}_{68} \mathrm{INO}\left[\mathrm{M}-\mathrm{I}^{-}\right]$: 482.5295 . Found: 482.5309 .

General procedure for synthesis of $N$-methyl, $N$-nonyloctadecan-1-amine (10). Nonanal $(0.21 \mathrm{~g}, 1.44 \mathrm{mmol})$ and $N$-methyl, $N$-octadecylamine $(0.41 \mathrm{~g}, 1.44 \mathrm{mmol})$ were dissolved in $10 \mathrm{~mL}$ methanol, $0.18 \mathrm{~g} \mathrm{NaBH}{ }_{3} \mathrm{CN}$ (2.88 mmol, 2 eq.) and $0.41 \mathrm{~mL}$ acetic acid ( $7.21 \mathrm{mmol}, 5$ eq.) were added sequentially. The reaction mixture was stirred overnight at room temperature, concentrated under reduced pressure and dissolved in ethyl acetate. The mixture was washed 3 times with a saturated $\mathrm{NaHCO}_{3}$ solution and the organic phase was dried over $\mathrm{MgSO}_{4}$, filtered and concentrated under reduced pressure. Compound 10 was isolated as a viscous colorless oil without further purification (0.57 g, 97\%). ${ }^{\mathbf{1}} \mathbf{H}$-NMR (400 $\mathbf{~ M H z}, \mathbf{C D C l}_{3}$ ): $\delta_{\mathbf{H}} 0.88\left(6 \mathrm{H}, \mathrm{t}, J=6.8 \mathrm{~Hz}, 2 \times \mathrm{CH}_{3} \mathrm{CH}_{2}\right), 1.25-1.32(42 \mathrm{H}, \mathrm{m}, 2 \times$ $\left.\mathrm{CH}_{3} \underline{\mathrm{CH}}_{2}, 19 \times \mathrm{CH}_{2}\left(\mathrm{CH}_{2}\right)_{2}\right), 1.44-1.50\left(4 \mathrm{H}, \mathrm{m}, 2 \times \mathrm{CH}_{2} \mathrm{CH}_{2} \mathrm{~N}\right)$, $2.23\left(3 \mathrm{H}, \mathrm{s}, \mathrm{CH}_{3} \mathrm{~N}\right), 2.32-2.36\left(4 \mathrm{H}, \mathrm{m}, 2 \times \mathrm{CH}_{2} \mathrm{~N}\right) .{ }^{\overline{13}} \mathrm{C}-\mathrm{NMR}$ $\left(100 \mathrm{MHz}, \mathrm{CDCl}_{3}\right): \delta_{\mathrm{C}} 14.1\left(2 \times \underline{\mathrm{CH}}_{3} \mathrm{CH}_{2}\right), 22.7\left(\underline{\mathrm{CH}}_{2} \mathrm{CH}_{2} \mathrm{~N}\right), 22.7$ $\left(\underline{\mathrm{CH}}_{2} \mathrm{CH}_{2} \mathrm{~N}\right), 27.1\left(2 \times \underline{\mathrm{CH}}_{2} \mathrm{CH}_{2} \mathrm{~N}\right), 27.6\left(2 \times \underline{\mathrm{CH}}_{2}\left(\mathrm{CH}_{2}\right)_{2}\right), 29.3$ $\left(\underline{\mathrm{C}} \mathrm{H}_{2}\left(\mathrm{CH}_{2}\right)_{2}\right), 29.4\left(\mathrm{CH}_{2}\left(\mathrm{CH}_{2}\right)_{2}\right), 29.6-29.7\left(13 \times \underline{\mathrm{CH}_{2}}\left(\mathrm{CH}_{2}\right)_{2}\right)$, $31.9\left(\underline{\mathrm{CH}}_{2}\left(\mathrm{CH}_{2}\right)_{2}\right), 31.9\left(\underline{\mathrm{CH}}_{2}\left(\mathrm{CH}_{2}\right)_{2}\right), 42.2\left(\underline{\mathrm{CH}}_{3} \mathrm{~N}\right), 57.8(2 \times$ $\mathrm{CH}_{2} \mathrm{~N}$ ). MS (ESI): $m / z$ exact mass calculated for $\mathrm{C}_{28} \mathrm{H}_{60} \mathrm{~N}$ $\left[\mathrm{M}+\mathrm{H}^{+}\right]$: 410.4720. Found: 410.4710 .

General procedure for synthesis of $\mathrm{N}, \mathrm{N}$-dimethyl, $\mathrm{N}$-nonyloctadecan-1-ammonium iodide (11a). In a $10 \mathrm{~mL}$ pressure resistant vial, $0.29 \mathrm{~g}$ of compound $10(0.70 \mathrm{mmol})$ was dissolved in a $1: 1$ mixture of acetone and acetonitrile. The solution was cooled down to $0{ }^{\circ} \mathrm{C}$ and $0.22 \mathrm{~mL}$ of methyl iodide (3.49 mmol, 5 eq.) was added. The vial was closed and heated to $80^{\circ} \mathrm{C}$ for 72 hours. The reaction mixture was concentrated under reduced pressure to yield compound 11a as an orange waxy solid (0.39 g, quant.). ${ }^{\mathbf{1}} \mathbf{H}-\mathbf{N M R}$ (400 $\mathbf{~ M H z}, \mathbf{C D C l}_{\mathbf{3}}$ ): $\boldsymbol{\delta}_{\mathbf{H}} 0.81$ $\left(6 \mathrm{H}, \mathrm{t}, J=6.7 \mathrm{~Hz}, 2 \times \mathrm{CH}_{3} \mathrm{CH}_{2}\right), 1.19-1.36(42 \mathrm{H}, \mathrm{m}, 2 \times$ $\left.\mathrm{CH}_{3} \underline{\mathrm{CH}}_{2}, 19 \times \mathrm{CH}_{2}\left(\mathrm{CH}_{2}\right)_{2}\right), 1.62-1.70\left(4 \mathrm{H}, \mathrm{m}, 2 \times \mathrm{CH}_{2} \mathrm{CH}_{2} \mathrm{~N}\right)$, $3.32\left(\overline{6} \mathrm{H}, \mathrm{s}, 2 \times \mathrm{CH}_{3} \mathrm{~N}\right), 3.44-3.48\left(4 \mathrm{H}, \mathrm{m}, 2 \times \mathrm{CH}_{2} \mathrm{~N}\right) .{ }^{{ }^{13}} \mathrm{C}-\mathrm{NMR}$ $\left(100 \mathrm{MHz}, \mathrm{CDCl}_{3}\right): \delta_{\mathrm{C}} 14.1\left(\mathrm{CH}_{3} \mathrm{CH}_{2}\right), 14.1\left(\underline{\mathrm{CH}}_{3} \mathrm{CH}_{2}\right), 22.6$ $\left(\mathrm{CH}_{3} \underline{\mathrm{CH}}_{2}\right), 22.7\left(\mathrm{CH}_{3} \underline{\mathrm{CH}}_{2}\right), 22.8\left(2 \times \underline{\mathrm{CH}}_{2} \mathrm{CH}_{2} \mathrm{~N}\right), 26.2(2 \times$ $\left.\underline{\mathrm{CH}}_{2}\left(\mathrm{CH}_{2}\right)_{2}\right), \quad 29.1 \quad\left(\underline{\mathrm{C}}_{2}\left(\mathrm{CH}_{2}\right)_{2}\right), \quad 29.2 \quad\left(\underline{\mathrm{CH}}_{2}\left(\mathrm{CH}_{2}\right)_{2}\right), \quad 29.2$

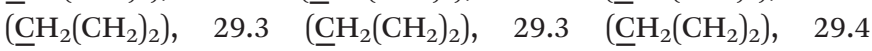
$\left(\underline{\mathrm{C}} \mathrm{H}_{2}\left(\mathrm{CH}_{2}\right)_{2}\right), 29.5\left(\underline{\mathrm{CH}}_{2}\left(\mathrm{CH}_{2}\right)_{2}\right), 29.6\left(\mathrm{CH}_{2}\left(\mathrm{CH}_{2}\right)_{2}\right), 29.6-29.7$ $\left(\overline{7} \times \underline{\mathrm{CH}_{2}}\left(\mathrm{CH}_{2}\right)_{2}\right), 31.8\left(\underline{\mathrm{CH}}_{2}\left(\mathrm{CH}_{2}\right)_{2}\right), 31.9\left(\underline{\mathrm{CH}}_{2}\left(\mathrm{CH}_{2}\right)_{2}\right), 51.6(2 \times$ $\left.\mathrm{CH}_{3} \mathrm{~N}\right), 64.2\left(2 \times \underline{\mathrm{CH}}_{2} \mathrm{~N}\right)$. MS (ESI): $\boldsymbol{m} / \boldsymbol{z}$ exact mass calculated for $\mathrm{C}_{29} \mathrm{H}_{62} \mathrm{~N}\left[\mathrm{M}-\mathrm{I}^{-}\right]$: 424.4877 . Found: 424.4881 .
General procedure for synthesis of $N$-butyl, $N$-methyl, $N$-nonyloctadecan-1-ammonium iodide (11b). In a $10 \mathrm{~mL}$ pressure resistant vial, $0.28 \mathrm{~g}$ of compound $10(0.70 \mathrm{mmol})$ was dissolved in a $1: 1$ mixture of acetone and acetonitrile. The solution was cooled down to $0{ }^{\circ} \mathrm{C}$ and $0.39 \mathrm{~mL}$ of butyl iodide (3.47 mmol, 5 eq.) was added. The vial was closed and heated to $80{ }^{\circ} \mathrm{C}$ for 72 hours. The reaction mixture was concentrated under reduced pressure to yield compound $\mathbf{1 1 b}$ as a yellow waxy solid (0.40 g, 97\%). ${ }^{1} \mathbf{H}-\mathbf{N M R}\left(400 \mathbf{~ M H z}, \mathbf{C D C l}_{3}\right.$ ): $\boldsymbol{\delta}_{\mathbf{H}} 0.88$ $\left(6 \mathrm{H}, \mathrm{t}, J=6.5 \mathrm{~Hz}, 2 \times \mathrm{CH}_{3} \mathrm{CH}_{2}\right), 1.02(3 \mathrm{H}, \mathrm{t}, J=7.3 \mathrm{~Hz}$, $\mathrm{CH}_{3} \mathrm{CH}_{2}$ ), 1.26-1.50 (44H, m, $\left.3 \times \mathrm{CH}_{3} \underline{\mathrm{CH}}_{2}, 19 \times \mathrm{CH}_{2}\left(\mathrm{CH}_{2}\right)_{2}\right)$, 1.67-1.76 (6H, m, $\left.3 \times \mathrm{CH}_{2} \mathrm{CH}_{2} \mathrm{~N}\right), 3.29\left(3 \overline{\mathrm{H}}, \mathrm{s}, \mathrm{CH}_{3} \mathrm{~N}\right), 3.42-3.50$ $\left(6 \mathrm{H}, \mathrm{m}, 3 \times \mathrm{CH}_{2} \mathrm{~N}\right) \cdot{ }^{13} \mathrm{C}-\mathbf{N M R}\left(100 \mathbf{M H z}, \mathbf{C D C l}_{3}\right): \delta_{\mathrm{C}} 13.8$ $\left(\underline{\mathrm{CH}}_{3} \mathrm{CH}_{2}\right), 14.1\left(\underline{\mathrm{CH}}_{3} \mathrm{CH}_{2}\right), 14.1\left(\underline{\mathrm{CH}}_{3} \mathrm{CH}_{2}\right), 19.7\left(\mathrm{CH}_{3} \underline{\mathrm{CH}}_{2}\right), 22.5$ $\left(2 \times \quad \underline{\mathrm{CH}}_{2} \mathrm{CH}_{2} \mathrm{~N}\right), \quad 22.6 \quad\left(\mathrm{CH}_{3} \underline{\mathrm{CH}}_{2}\right), \quad 22.7 \quad\left(\mathrm{CH}_{3} \underline{\mathrm{CH}}_{2}\right), \quad 24.5$ $\left(\underline{\mathrm{CH}}_{2} \mathrm{CH}_{2} \mathrm{~N}\right), 26.3\left(2 \times \underline{\mathrm{CH}}_{2}\left(\mathrm{CH}_{2}\right)_{2}\right), 29.1\left(\underline{\mathrm{CH}}_{2}\left(\mathrm{CH}_{2}\right)_{2}\right), 29.2$

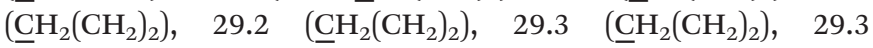
$\left(\underline{\mathrm{CH}}_{2}\left(\mathrm{CH}_{2}\right)_{2}\right), \quad 29.4 \quad\left(\underline{\mathrm{CH}}_{2}\left(\mathrm{CH}_{2}\right)_{2}\right), \quad 29.5 \quad\left(\underline{\mathrm{CH}}_{2}\left(\mathrm{CH}_{2}\right)_{2}\right), \quad 29.6$ $\left(\underline{\mathrm{CH}_{2}}\left(\mathrm{CH}_{2}\right)_{2}\right), 29.6-29.7\left(7 \times \mathrm{CH}_{2}\left(\mathrm{CH}_{2}\right)_{2}\right), 31.8\left(\underline{\mathrm{CH}}_{2}\left(\mathrm{CH}_{2}\right)_{2}\right), 31.9$ $\left(\underline{\mathrm{CH}}_{2}\left(\mathrm{CH}_{2}\right)_{2}\right), 49.3\left(\mathrm{CH}_{3} \mathrm{~N}\right), 61.7\left(\mathrm{CH}_{2} \mathrm{~N}\right), 61.8\left(2 \times \mathrm{CH}_{2} \mathrm{~N}\right) . \mathbf{M S}$ (ESI): $\boldsymbol{m} / \boldsymbol{z}$ exact mass calculated for $\mathrm{C}_{32} \mathrm{H}_{68} \mathrm{~N}\left[\mathrm{M}-\mathrm{I}^{-}\right]$: 466.5346. Found: 466.5356 .

\section{Materials and methods}

\section{General instrumental methods}

Commercially available products were used without further purification. NMR spectra were recorded at $400 \mathrm{MHz}\left({ }^{1} \mathrm{H}\right)$ and $100 \mathrm{MHz}\left({ }^{13} \mathrm{C}\right)$ in $\mathrm{CDCl}_{3}$ or $\mathrm{MeOD}$ with a Bruker Avance III Nanobay $400 \mathrm{MHz}$ spectrometer at room temperature. Lowresolution mass spectra were recorded with a single quadrupole mass spectrometer (ESI, $70 \mathrm{eV}$ ). High-resolution mass spectra were obtained with a time-of-flight (TOF) mass spectrometer (ESI or APCI).

\section{Liposome formulations}

The liposomal solutions were prepared by hydration of a lipid film. A $1.5 \mathrm{mM}$ solution (1 mL) of each compound was prepared in chloroform, formulated with or without DOPE (1:1 compound/DOPE) and evaporated under reduced pressure to produce a thin lipid film. Water $(1 \mathrm{~mL})$ was added to rehydrate this lipid film in a time period of 7 days at room temperature. The solution was vortexed (10 s) and sonicated $(30 \mathrm{~min}$ at $50{ }^{\circ} \mathrm{C}$ ) at $45 \mathrm{kHz}$ using a VWR ultrasonic bath. The size and zeta potential were determined for each liposomal formulation.

\section{DNA complexation}

Lipoplexes were prepared by mixing pDNA (pEGFP-Luc, Clontech) with each liposomal solution in Opti-MEM (Gibco). Addition of pDNA to the liposomal solutions was performed at concentrations corresponding to CR ranging from 1 to 8 . The obtained mixtures were incubated at room temperature for 1 hour before being subjected to electrophoresis in a $0.8 \%$ agarose gel at $100 \mathrm{~V}, 90 \mathrm{~mA}$. The gel was previously stained 
with SYBR gold nucleic acid gel staining (Life Technologies) and visualized using a UV transilluminator (Fischer Bioblock).

\section{Transfection efficiency}

The in vitro reporter gene assay via the luciferase measurement was carried out as reported previously. ${ }^{9 b, 20}$ In short, the four cell lines were grown in either EMEM (16HBE) or DMEM (A549, SKMEL28 and C2C12) both supplemented with 10\% bovine fetal serum, 1\% antibiotic and 1\% L-glutamine. All incubations were performed at $37{ }^{\circ} \mathrm{C}$ in a humidified atmosphere containing $5 \% \mathrm{CO}_{2}$. The day before transfection, the cells were seeded into a 96-well plate at a density of 25000 cells per well. Lipoplexes were prepared as detailed above and then added dropwise to each well; the commercial formulation Lipofectamine Reagent (Invitrogen) was used as a positive transfection control whereas naked DNA was used as a negative control. After $48 \mathrm{~h}$ at $37{ }^{\circ} \mathrm{C}$, the culture medium was removed and the cells were lysed with Passive Lysis Buffer (Promega) prior to examination via a chemiluminescence assay (Luciferase Assay System, Promega) to determine the luciferase expression. The total protein content of each cell lysate was determined using the BC assay kit (Uptima). Finally, data were expressed as relative light units (RLU) per milligram of total proteins (mean \pm SD with $n=3$ ).

\section{Cell viability}

The cell viability was considered to estimate the toxicity resulting from the exposure of the cells to the lipoplexes. For this purpose, the ViaLight kit (Lonza) was used to determine the ATP content which reflects the number of living cells (transfected or not) in culture, as a result of both cell proliferation and cell mortality (either normal or experimentally-induced) that occurred during the 48 hours of the experiment. This assay was used as recommended by the manufacturer. The results were expressed as percentages relative to the viability of non-transfected cells used as the reference $(100 \%$ cell viability).

\section{Acknowledgements}

The research leading to these results has received funding from the Long Term Structural Methusalem funding by the Flemish Government (grant number BOF09/01M00409).

\section{Notes and references}

1 F. Perche, T. Benvegnu, M. Berchel, L. Lebegue, C. Pichon, P. A. Jaffres and P. Midoux, Nanomedicine, 2011, 7, 445453.

2 A. K. K. Leung, Y. Y. C. Tam and P. R. Cullis, Adv. Genet., 2014, 88, 71-110.

3 (a) X. Guo and L. Huang, Acc. Chem. Res., 2012, 45, 971979; (b) M. Berchel, T. Le Gall, H. Couthon-Gourves, J. P. Haelters, T. Montier, P. Midoux, P. Lehn and
P. A. Jaffres, Biochimie, 2012, 94, 33-41; (c) T. Montier, T. Benvegnu, P. A. Jaffres, J. J. Yaouanc and P. Lehn, Curr. Gene Ther., 2008, 8, 296-312.

4 P. L. Felgner, T. R. Gadek, M. Holm, R. Roman, H. W. Chan, M. Wenz, J. P. Northrop, G. M. Ringold and M. Danielsen, Proc. Natl. Acad. Sci. U. S. A., 1987, 84, 74137417.

5 (a) L. Billiet, J. P. Gomez, M. Berchel, P. A. Jaffres, T. Le Gall, T. Montier, E. Bertrand, H. Cheradame, P. Guegan, M. Mevel, B. Pitard, T. Benvegnu, P. Lehn, C. Pichon and P. Midoux, Biomaterials, 2012, 33, 2980-2990; (b) V. Laurent, A. Fraix, T. Montier, S. Cammas-Marion, C. Ribault, T. Benvegnu, P. A. Jaffres and P. Loyer, Biotechnol. J., 2010, 5, 314-320; (c) M. H. Nantz, C. W. Dicus, B. Hilliard, S. Yellayi, S. M. Zou and J. G. Hecker, Mol. Pharmaceutics, 2010, 7, 786-794.

6 E. W. F. W. Alton, D. K. Armstrong, D. Ashby, K. J. Bayfield, D. Bilton, E. V. Bloomfield, A. C. Boyd, J. Brand, R. Buchan, R. Calcedo, P. Carvelli, M. Chan, S. H. Cheng, D. D. S. Collie, S. Cunningham, H. E. Davidson, G. Davies, J. C. Davies, L. A. Davies, M. H. Dewar, A. Doherty, J. Donovan, N. S. Dwyer, H. I. Elgmati, R. F. Featherstone, J. Gavino, S. Gea-Sorli, D. M. Geddes, J. S. R. Gibson, D. R. Gill, A. P. Greening, U. Griesenbach, D. M. Hansell, K. Harman, T. E. Higgins, S. L. Hodges, S. C. Hyde, L. Hyndman, J. A. Innes, J. Jacob, N. Jones, B. F. Keogh, M. P. Limberis, P. Lloyd-Evans, A. W. Maclean, M. C. Manvell, D. McCormick, M. McGovern, G. McLachlan, C. X. Meng, M. A. Montero, H. Milligan, L. J. Moyce, G. D. Murray, A. G. Nicholson, T. Osadolor, J. Parra-Leiton, D. J. Porteous, I. A. Pringle, E. K. Punch, K. M. Pytel, A. L. Quittner, G. Rivellini, C. J. Saunders, R. K. Scheule, S. Sheard, N. J. Simmonds, K. Smith, S. N. Smith, N. Soussi, S. Soussi, E. J. Spearing, B. J. Stevenson, S. G. Sumner-Jones, M. Turkkila, R. P. Ureta, M. D. Waller, M. Y. Wasowicz, J. M. Wilson, P. Wolstenholme-Hogg and U. C. F. G. T. Co, Lancet Respir. Med., 2015, 3, 684-691.

7 (a) M. F. Lindberg, T. Le Gall, N. Carmoy, M. Berchel, S. C. Hyde, D. R. Gill, P. A. Jaffres, P. Lehn and T. Montier, Biomaterials, 2015, 59, 1-11; (b) J. Y. Sun, V. Anand-Jawa, S. Chatterjee and K. K. Wong, Gene Ther., 2003, 10, 964976.

8 P. Midoux, C. Pichon, J. J. Yaouanc and P. A. Jaffres, Br. J. Pharmacol., 2009, 157, 166-178.

9 (a) D. L. Liu, W. H. Qiao, Z. S. Li, Y. X. Chen, X. Y. Cui, K. Li, L. H. Yu, K. L. Yan, L. M. Zhu, Y. L. Guo and L. B. Cheng, Chem. Biol. Drug Des., 2008, 71, 336-344; (b) S. S. Le Corre, M. Berchel, T. Le Gall, J. P. Haelters, P. Lehn, T. Montier and P. A. Jaffres, Eur. J. Org. Chem., 2014, 8041-8048; (c) T. Le Gall, D. Loizeau, E. Picquet, N. Carmoy, J. J. Yaouanc, L. Burel-Deschamps, P. Delepine, P. Giamarchi, P. A. Jaffres, P. Lehn and T. Montier, J. Med. Chem., 2010, 53, 1496-1508; (d) M. F. Lindberg, N. Carmoy, T. Le Gall, A. Fraix, M. Berchel, C. Lorilleux, H. CouthonGourves, P. Bellaud, A. Fautrel, P. A. Jaffres, P. Lehn and 
T. Montier, Biomaterials, 2012, 33, 6240-6253; (e) R. Koynova, B. Tenchov, L. Wang and R. C. MacDonald, Mol. Pharmaceutics, 2009, 6, 951-958; (f) H. S. Rosenzweig, V. A. Rakhmanova, T. J. McIntosh and R. C. MacDonald, Bioconjugate Chem., 2000, 11, 306-313; (g) R. C. MacDonald, V. A. Rakhmanova, K. L. Choi, H. S. Rosenzweig and M. K. Lahiri, J. Pharm. Sci., 1999, 88, 896-904; (h) P. Belmont, A. Aissaoui, M. Hauchecorne, N. Oudrhiri, L. Petit, J. P. Vigneron, J. M. Lehn and P. Lehn, J. Gene Med., 2002, 4, 517-526; (i) M. Sainlos, P. Belmont, J. P. Vigneron, P. Lehn and J. M. Lehn, Eur. J. Org. Chem., 2003, 2764-2774; (j) N. Niyomtham, N. Apiratikul, K. Suksen, P. Opanasopit and B. E. Yingyongnarongkul, Bioorg. Med. Chem. Lett., 2015, 25, 496-503; (k) F. Lamarche, M. Mevel, T. Montier, L. Burel-Deschamps, P. Giamarchi, R. Tripier, P. Delepine, T. Le Gall, D. Cartier, P. Lehn, P. A. Jaffrees and J. C. Clement, Bioconjugate Chem., 2007, 18, 1575-1582; (l) C. Paris, V. Moreau, G. Deglane, L. Karim, B. Couturier, M. E. Bonnet, V. Kedinger, M. Messmer, A. L. Bolcato-Bellemin, J. P. Behr, P. Erbacher and N. Lenne-Samuel, Mol. Pharmaceutics, 2012, 9, 3464-3475; ( $m$ ) O. Paecharoenchai, N. Niyomtham, T. Ngawhirunpat, T. Rojanarata, B. E. Yingyongnarongkul and P. Opanasopit, J. Drug Targeting, 2012, 20, 783-792; (n) A. Fraix, T. Montier, T. Le Gall, C. M. Sevrain, N. Carmoy, M. F. Lindberg, P. Lehn and P. A. Jaffres, Org. Biomol. Chem., 2012, 10, 2051-2058.

10 (a) S. Fukuda, M. Terasawa and K. Shiomi, Food Chem. Toxicol., 2011, 49, 1598-1603; (b) T. Le Gall, M. Berchel, S. Le Hir, A. Fraix, J. Y. Salaun, C. Ferec, P. Lehn, P. A. Jaffres and T. Montier, Adv. Healthcare Mater., 2013, 2, 1513-1524.

11 (a) I. N. A. Van Bogaert, K. Saerens, C. De Muynck, D. Develter, W. Soetaert and E. J. Vandamme, Appl. Microbiol. Biotechnol., 2007, 76, 23-34; (b) I. N. A. Van Bogaert, J. X. Zhang and W. Soetaert, Process Biochem., 2011, 46, 821-833.

12 (a) P. Andre and F. Pellicier, WO 2004108063, 2004 (LVMH Recherche); (b) M. H. Bluth, E. Kandil, C. M. Mueller, V. Shah, Y. Y. Lin, H. Zhang, L. Dresner, L. Lempert, M. Nowakowski, R. Gross, R. Schulze and M. E. Zenilman, Crit. Care Med., 2006, 34, 188-195; (c) F. Borzeix Concaix, US Pat, 6596265, 1999 (Institut Françcais du Pétrole, Sophor S.A.); (d) J. Chen, X. Song, H. Zhang, Y. B. Qu and J. Y. Miao, Appl. Microbiol. Biotechnol., 2006, 72, 52-59; (e) E. I. P. Delbeke, M. Movsisyan, K. M. Van Geem and C. V. Stevens, Green Chem., 2016, 18, 76-104; (f) S. L. Fu, S. R. Wallner, W. B. Bowne, M. D. Hagler, M. E. Zenilman, R. Gross and M. H. Bluth, J. Surg. Res., 2008, 148, 77-82; (g) R. A. Gross and V. Shah, WO 2004044216, 2002
(Polytechnic University); (h) R. A. Gross and V. Shah, WO 2007130738, 2007 (Polytechnic University); (i) R. A. Gross, V. Shah and G. F. Doncel, US Pat, 2011/0 223 239, 2011 (Gross, R.A., Shah, V., Doncel, G.F.); (j) R. Hardin, J. Pierre, R. Schulze, C. M. Mueller, S. L. Fu, S. R. Wallner, A. Stanek, V. Shah, R. A. Gross, J. Weedon, M. Nowakowski, M. E. Zenilman and M. H. Bluth, J. Surg. Res., 2007, 142, 314-319; ( $k$ ) C. Jing, S. Xin, Z. Hui and Y. B. Qu, Enzyme Microb. Technol., 2006, 39, 501-506; (l) V. K. Morya, C. Ahn, S. Jeon and E. K. Kim, Mini-Rev. Med. Chem., 2013, 13, 1761-1768; $(m)$ V. Shah, D. Badia and P. Ratsep, Antimicrob. Agents Chemother., 2007, 51, 397-400; (n) V. Shah, G. F. Doncel, T. Seyoum, K. M. Eaton, I. Zalenskaya, R. Hagver, A. Azim and R. Gross, Antimicrob. Agents Chemother., 2005, 49, 4093-4100; (o) L. J. Shao, X. Song, X. J. Ma, H. Li and Y. B. Qu, J. Surg. Res., 2012, 173, 286291.

13 (a) N. Baccile, N. Nassif, L. Malfatti, I. N. A. Van Bogaert, W. Soetaert, G. Pehau-Arnaudet and F. Babonneau, Green Chem., 2010, 12, 1564-1567; (b) N. Baccile, F. Babonneau, J. Jestin, G. Pehau-Arnaudet and I. Van Bogaert, ACS Nano, 2012, 6, 4763-4776; (c) N. Baccile, J. S. Pedersen, G. PehauArnaudet and I. N. A. Van Bogaert, Soft Matter, 2013, 9, 4911-4922; (d) A. S. Cuvier, J. Berton, C. V. Stevens, G. C. Fadda, F. Babonneau, I. N. A. Van Bogaert, W. Soetaert, G. Pehau-Arnaudet and N. Baccile, Soft Matter, 2014, 10, 3950-3959; (e) A. S. Cuvier, F. Babonneau, J. Berton, C. V. Stevens, G. C. Fadda, I. Genois, P. Le Griel, G. Pehau-Arnaudet and N. Baccile, Chem. - Asian J., 2015, 10, 2419-2426; $(f)$ N. Baccile, R. Noiville, L. Stievano and I. Van Bogaert, Phys. Chem. Chem. Phys., 2013, 15, 16061620.

14 S. Dhar, E. M. Reddy, A. Prabhune, V. Pokharkar, A. Shiras and B. L. V. Prasad, Nanoscale, 2011, 3, 575-580.

15 E. I. P. Delbeke, B. I. Roman, G. B. Marin, K. M. Van Geem and C. V. Stevens, Green Chem., 2015, 17, 3373-3377.

16 V. D. Sharma, J. Lees, N. E. Hoffman, E. Brailoiu, M. Madesh, S. L. Wunder and M. A. Ilies, Mol. Pharmaceutics, 2014, 11, 545-559.

17 K. H. Han, Nucleic Acids Res., 1996, 24, 4362-4363.

18 P. Pinnaduwage, L. Schmitt and L. Huang, Biochim. Biophys. Acta, 1989, 985, 33-37.

19 (a) M. Berchel, T. Le Gall, J. P. Haelters, P. Lehn, T. Montier and P. A. Jaffres, Mol. Pharmaceutics, 2015, 12, 1902-1910; (b) S. S. Le Corre, N. Belmadi, M. Berchel, T. Le Gall, J. P. Haelters, P. Lehn, T. Montier and P. A. Jaffres, Org. Biomol. Chem., 2015, 13, 1122-1132.

20 A. Fraix, T. Le Gall, M. Berchel, C. Denis, P. Lehn, T. Montier and P. A. Jaffres, Org. Biomol. Chem., 2013, 11, 1650-1658. 